\title{
Managing the risks of switch bills of lading
}

\author{
Miriam Goldby* \\ Final as at $28^{\text {th }}$ May 2019
}

\section{A. Introduction}

The practice of issuing switch bills of lading, while quite prevalent internationally has not received much attention in the legal literature. Although the issue of switch bills is in many cases done for legitimate reasons and serves to facilitate trade, issuance is often effected without a proper understanding of the risks involved. ${ }^{1}$ Indeed, the legal nature and character of switching has not to date been analysed in depth, and a number of open questions remain regarding the legal nature, effect and consequences of these practices. The purpose of this paper is to analyse a number of cases decided in the common law courts so as to attempt to answer the questions: what happens in legal terms when a switch bill of lading is issued? What are the legal risks involved? And how may these risks best be managed and mitigated?

\section{B. What is switching and why is it done?}

As the name suggests a switch bill of lading is one which is issued in substitution for the original bill of lading issued to the shipper at the time of receipt of the goods or of loading. The switch bill is usually issued at a port other than the port of loading. Bills may be switched anywhere in the world where the issuer has an office or an authorised agent.

The reasons for requesting a switch bill are various, many of them quite legitimate. A circular from the International Transport Intermediaries Club (ITIC) lists some of the most common ones as follows:

- the original bill names a discharge port which is subsequently changed (e.g. because the goods have been resold and new bills are required naming a new discharge port);

- a seller of the goods in a chain of contracts does not wish the name of the original shipper to appear on the bills, and so a new set ... naming the seller as the shipper is issued;

- the goods were shipped originally in small parcels, and the buyer of those goods requires one bill of lading covering all of the parcels to facilitate his onsale. Conversely one bill may be issued for a bulk shipment which is then to be split into multiple bills covering smaller parcels. ${ }^{2}$

Published cases also give various indications as to what might be the reasons for requesting the issue of switch bills. In Bandung ${ }^{3}$ the court observed that 'the altering [by the issue of a switch bill] of details [entered into the original bill] may be for a number of reasons such as

\footnotetext{
* Reader in Shipping, Insurance and Commercial Law at the Centre for Commercial Law Studies, Queen Mary University of London. I would like to thank Prof. Sir Richard Aikens and Prof. Paul Myburgh for their invaluable comments on an earlier draft of the paper. All errors remain my own.

${ }^{1}$ M Jagannath, 'Switch Bills of Lading - Revisited', NAU Newsletter, $10^{\text {th }}$ August 2014, available electronically at http://nau.com.sg/articles detail.php?id=71 (accessed 30-06-2017).

${ }^{2}$ International Transport Intermediaries Club, Issuance of Switch Bill of Lading, 2013, 1.

${ }^{3}$ BNP Paribas v Bandung Shipping [2003] SGHC 111 (High Court of Singapore) (hereinafter "Bandung").
} 
to conceal the origin of the goods, ${ }^{4}$ identity of the original shipper, date of shipment or due to on-board commingling.... ${ }^{5}$ With regard to a bill issued to conceal the origin of the goods, an example may be found in Seyou Products, ${ }^{6}$ a Singapore case, where goods originally shipped in Korea were transhipped in Singapore and the bills of lading were switched to ones showing Singapore as the load port and changing the shipper's name, in order to keep the source of the cargo confidential. ${ }^{7}$ But the reasons for requesting a switch bill showing a different load port may be more problematic, for example to circumvent sanctions against certain states. ${ }^{8}$ Published cases also demonstrate that switch bills are sometimes requested to

\footnotetext{
${ }^{4}$ This is borne out in H Manaadiar 'What is a switch bill of lading and when and why is it used?', Shipping and Freight Resource, $6^{\text {th }}$ June 2012, available electronically at: https://shippingandfreightresource.com/what-is-aswitch-bill-of-lading-and-when-and-why-is-it-used/ (accessed 30-06-2017): 'The seller does not want [...] the buyer to know the actual country of origin of the cargo so he requests that the port of loading be shown as some port other than the one the cargo was loaded from.'

${ }^{5}$ Bandung (n 3), [15]. Re onboard commingling and blending see B E Nergardt, 'Redocumentation of Cargoes in the Tanker Trade', paper presented at the International Congress of Maritime Arbitrators, Hong Kong, $12^{\text {th }}$ May 2015.

${ }^{6}$ Seyou Products Corporation v Midfa Corporation Pte Ltd [2003] SGDC 141 (Singapore District Court) (hereinafter "Seyou Products").

${ }^{7}$ Seyou Products (n 6), [109].

${ }^{8}$ For example, as of $7^{\text {th }}$ November 2018, the United States (US) withdrew from the Joint Comprehensive Plan of Action concluded on $14^{\text {th }}$ July 2015 by China, France, Germany, the Russian Federation, the United Kingdom, the United States, the European Union and Iran and endorsed by the United Nations Security Council through its Resolution 2231 on $20^{\text {th }}$ July 2015. This withdrawal meant that all US sanctions against Iran in place prior to the conclusion of the agreement were reinstated. Of particular interest for the purposes of this paper are sanctions prohibiting import and export transactions and the provision of shipping and insurance services. The sanctions regime is complex and underpinned by many different pieces of legislation and executive orders (see in particular the Comprehensive Iran Sanctions, Accountability, and Divestment Act of 2010 (as amended) and the Iranian Transactions and Sanctions Regulations (ITSR) 31 US Code of Federal Regulations (CFR) 560 (as amended)). Resources may be found at the US Department of Treasury Resource Center: Iran Sanctions, online at https://www.treasury.gov/resource-center/sanctions/Programs/Pages/iran.aspx [accessed 29 March 2019]. Particularly useful are the answers to Frequently Asked Questions (FAQs) https://www.treasury.gov/resourcecenter/faqs/Sanctions/Pages/faq iran.aspx [accessed 29 March 2019] (see especially FAQs 614-620 on Sanctions on Petroleum-related Transactions). See also See the Specially Designated Nationals and Blocked Persons (SDN) List, online at https://sanctionssearch.ofac.treas.gov/ [accessed 29 March 2019]. As an example, 74 vessels and 383 entities are sanctioned in connection with the Iran sanctions programme, the latter including banks, exporters and shipping companies. The sanctions prohibit dealings with these entities by US citizens and block the companies' financial interests in the US. The Office of Foreign Assets Control (OFAC) has also published guidance on how the Islamic Republic of Iran Shipping Lines (IRISL) hide their involvement in shipping transactions in order to circumvent sanctions (see OFAC, Presentation of Fraudulent Shipping Documents, $31^{\text {st }}$ March 2011, available online at https://www.treasury.gov/resourcecenter/sanctions/Programs/Documents/20110331 advisory.pdf [accessed 29 March 2019]), and on how to avoid falling foul of sanctions prohibiting exports to Iran (see Guidance on Transshipments to Iran, 22 ${ }^{\text {nd }}$ July 2002 , available online at https://www.treasury.gov/resource-center/sanctions/Programs/Documents/iranship.pdf [accessed 29 March 2019]). As these are unilateral sanctions imposed by the US with extraterritorial effect, other jurisdictions most notably the European Union, have responded with Blocking legislation, which raises challenging compliance issues. See Council Regulation (EC) No 2271/96 of 22 November 1996 protecting against the effects of the extra-territorial application of legislation adopted by a third country, and actions based thereon or resulting therefrom OJ L 309, 29.11.1996, p. 1-6. For a discussion of the business implications, see Chatham House, International Sanctions: Complexities and the Impact on European Businesses, Meeting Summary, 25 ${ }^{\text {th }}$ April 2012, available online at https://www.chathamhouse.org/sites/default/files/public/Research/International\%20Law/250412summary.pdf [accessed 15 April 2019] and J Dizard, 'Trying to Bypass US Sanctions on Iran is Futile', Financial Times, $26^{\text {th }}$ April 2019. Sanctions against other states, e.g. more recent sanctions against Venezuela, can also be relevant to the shipping industry. See D Brunnstrom, M Brice and T Ahmann, 'U.S. Slaps Sanctions on Shipping Firms, Ships Carrying Oil from Venezuela', Reuters World News, $13^{\text {th }}$ April 2019, available online at https://www.reuters.com/article/us-venezuela-politics-usa/u-s-slaps-sanctions-on-four-shipping-firms-nineships-carrying-oil-from-venezuela-idUSKCN1RO29D [accessed 15 April 2019].
} 
change the cargo description, ${ }^{9}$ and here again the reason for requesting the switch might be problematic, for example if it involves circumvention of import restrictions applying to the cargo as originally described. ${ }^{10}$ As shall be seen in sections $\mathrm{C}$ and $\mathrm{D}$ below, the reasons for switching may have an impact on the legal effect of the switch as well as the risks that arise as a result of switching.

\section{A legal analysis of switching bills of lading}

This part seeks to address the legal issues that may arise as a result of the issue of a switch bill of lading. While the main focus is on the effects of switching on the contractual nexus among different participants and on the terms of the contract, as shall be seen in section C.1, title to sue and liability to be sued may also be affected if certain changes are made to the content of the bill of lading upon switching. Further, as shall be seen in section C.4, the failure to take the original bill out of circulation when issuing a switch bill can create ambiguity as to who is entitled to delivery of the goods. The issues that will be discussed in this part are as follows.

The first issue (discussed in section C.1) concerns the legal effects of the switch. As explained, a switch bill is a fresh bill of lading issued in place of an existing bill of lading that embodies contractual rights and obligations, and the lawful holder of which has constructive possession of the goods. With respect to the contractual rights and obligations, it is necessary to address the question whether the switch (i) creates a new contract, (ii) varies the old contract or simply (iii) replaces the evidence of the contract. The answer will depend on what information is being changed between the old bill and the new. If for example the switch bill is being issued to correct an error in the description of the cargo, one might say that the switch is simply a ministerial act, and it is just the evidence of the original contract that is being replaced. If, however, there is a change in one of the contractual parties, or a change in one of the terms to be performed, for example the port of discharge, the switch bill in these cases may more accurately be described as a novation or a variation of the contract.

The second legal issue, addressed in section C.2, is the question of who may request the switch. A transfer of a bill of lading creates a contractual nexus between the issuer (the carrier) and its lawful holder. But the carriage service may also be governed by other contractual arrangements, commonly a charterparty (or string of charterparties) in the bulk trades, with the original shipper of the goods being also a charterer or sub-charterer. Where the carrier has contractual obligations towards more than one party with respect to a cargo carriage service it is providing, care must be exercised to ensure that an agreement with one of these parties to issue a switch bill does not constitute a breach of the obligations it has undertaken towards the other.

Third, a valid switch may not occur without the consent of the issuer of the original document. The holder of a switch bill of lading may find itself having paid for the goods it purports to cover without having obtained any rights against the carrier or constructive possession of those goods if the switch occurred without the issuer's authority. It is thus important to consider when the carrier may be taken to have consented to the issue of the switch bill. This is discussed in section C.3.

\footnotetext{
${ }^{9}$ Feoso (Singapore) Ltd v Faith Maritime Co Ltd [2003] SGCA 34 (Singapore Court of Appeal) (hereinafter "Feoso").

${ }^{10}$ Feoso (n 9), [63]-[65].
} 
Fourthly, even if the carrier has consented to (or is deemed to have authorised) the issue of the switch bill, if the original bill of lading remains in circulation, both the holder of the old bill and the holder of the switch bill will have rights of suit against the carrier, whose liability to one or other for breach of contract (and possibly conversion of the goods) will be inevitable. Yet case law suggests that it is not uncommon for switch bills to be issued against a letter of indemnity (LOI) ${ }^{11}$ without the original bills being surrendered back to the carrier. It is thus important to examine the legal position in these circumstances. This is done in section C.4.

Finally, the issue of a switch bill may raise questions as to what international transport convention applies to the contract of carriage, as the place of issue of the bill may be a significant factor determining applicability. A discussion of how these questions might be answered is found in section C.5.

\section{C.1 Does the issue of a switch bill constitute novation? Is it a variation of contract?}

The only attempt to analyse legal issues raised by switch bills legally which this author is aware is an article by Toh Kian Sing dated $1996 .{ }^{12}$ According to Toh, while the original bill of lading becomes spent upon its surrender and cancellation when the switch bill is issued,

'the contract of carriage still subsists, even if in the course of the voyage it is evidenced or contained in one and then, after the switch, in the other bill.' ${ }^{13}$

This seems to suggest that the surrender and cancellation of the bill of lading and the issue of the switch bill simply creates new evidence of the contract of carriage, while the contract itself remains unchanged. While this may well apply in the context in which it was said (i.e. a discussion of whether Hague-Visby imposed rights and obligations survive the switch, discussed in section C.5 below), it is submitted that the general contention that the original contract survives would not always hold. It may be true of a situation such as that in Finmoon, ${ }^{14}$ where the bill of lading issued at the load port was surrendered, cancelled and replaced by an identical document with no changes, issued at the discharge port. But it cannot be true of a document which changes the name of one of the parties or changes the point of departure or arrival or changes the quantity to be delivered. In these situations, it is submitted that the cancellation of the original bill and the issue of the switch bill need to be analysed in terms of a novation or variation of contract. Any implications in terms of rights of suit and liability to be sued also need to be addressed.

\footnotetext{
${ }^{11}$ See Mees Pierson NVv Bay Pacific (S) Pte Ltd and others [2000] SGHC 168 (High Court of Singapore), [18] where the evidence of Mr Edwin Tan ("Tan"), the employee in charge of handling documentation at the defendant trading company which in this case was the beneficiary under a letter of credit agreement, is summarised: 'Under cross-examination, Tan agreed that it was not his role to procure switched bills of lading. That, he asid, would be done by the traders employed by the [trading company] or by Pegasus High Seas Pte Ltd, a firm of shipping agents ... operating from the same premises as [the trading company]. Tan agreed that to obtain switched bills of lading either the original bills of lading would have to be surrendered to the shipping agent or an indemnity would have to be given....' This gives the impression that it is not unusual to issue switch bills in the absence of the original bills - a highly risky practice.

${ }^{12}$ KS Toh, 'Of Straight and Switch Bills of Lading' [1996] Lloyd's Maritime and Commercial Law Quarterly 416.

${ }^{13}$ Toh (n 12), 421.

${ }^{14}$ Finmoon Ltd v Baltic Reefers Management Ltd [2012] EWHC 920 (Comm).
} 
One of the most common legitimate reasons for switching bills of lading is to change the name of the shipper or consignee. ${ }^{15}$ A change of this type may be characterised as a novation of the contract of carriage, as designation as either shipper or consignee in a bill of lading can have contractual significance. ${ }^{16}$ Novation consists of the replacement of one party to a contract by a third party and is effective provided all parties involved consent to the replacement. ${ }^{17}$ Its effect is to extinguish the original contract and replace it by another, meaning that it is not necessary that new consideration should be provided for the new contract. ${ }^{18}$ As aptly put in Chitty, '[i]f A owes B money and both parties agree with $\mathrm{C}$ that $\mathrm{C}$, not $\mathrm{A}$, is to pay the money to $\mathrm{B}, \mathrm{B}$ provides consideration for C's promise to pay him by agreeing to release A; while A provides consideration for B's promise to release him by providing the new debtor, C. ${ }^{19}$

In the case of a switch bill of lading, it is with the issuer of the bill of lading that the major performance obligations lie, so that B in the Chitty scenario may be better characterised as the debtor rather than the creditor. $\mathrm{C}$ may be the new consignee or the new shipper adopting A's rights (and also any obligations attributable to persons in that role) under the contract. If B is the carrier (i.e. the issuer of the bill of lading), B's consent to this switch may be given in advance, for example by the inclusion of an appropriate clause in the contract between shipowner and charterer. That consent to novation may be given in advance in this way was confirmed in Habibsons Bank Ltd v Standard Chartered Bank ${ }^{20}$ where it was held that '[a]lthough there has been some discussion in the authorities about the principles involved, there has hitherto been no real doubt that under English law a party to a contract may effectively give consent in the contract itself to a subsequent novation.' Such a clause does not need to use the word "novation" in order to achieve the desired effect. ${ }^{21}$

\section{C.1.1 Change of shipper}

A change in the shipper's name through the device of issuing a switch bill of lading would be problematic if the inclusion of the name of the shipper in the original bill is viewed as a statement of fact (i.e. an indication of who in fact shipped the goods). On this view, a change in the shipper's name may well amount to a fraudulent misrepresentation on the part of the issuer of the switch bill (see discussion in section D.2 below). Commercial reality however demands that buyers who are on-selling the goods bought to their own sub-buyers should be able to keep their sources confidential, and, in many circumstances, this can only be achieved

\footnotetext{
${ }^{15}$ NAU, a claims correspondent/consultancy firm based at Singapore dealing with Transport Liability, Protection and Indemnity (P\&I) and Hull and Machinery (H\&M) Claims advises: 'The details which can be amended are the details of the Shipper, Consignee and / or notify party. If a request for the change in cargo or any other details is requested, Carriers should not agree as any changes of this sought [sic] would be akin to participating in fraud.' Jagannath (n 1).

${ }^{16}$ See discussion in sections C.1.1 and C.1.2 below.

17 See Damon Compania Naviera SA v. Hapag-Lloyd International SA, (The Blankenstein), [1985] 1 Lloyd's Rep. 93; [1985] 1 W.L.R. 435.

18 Tatlock $v$ Harris (1789) 3 TR 174, 180: 'suppose A owes B £100, and B owes C $£ 100$, and the three meet, and it is agreed between them that A shall pay $\mathrm{C}$ the $£ 100$; B's debt is extinguished, and $\mathrm{C}$ may recover that sum against A.'

${ }^{19} \mathrm{H}$ Beale, Chitty on Contracts, (32 ${ }^{\text {nd }}$ ed incorporating first supplement, Sweet \& Maxwell, 2016), 19-089.

${ }^{20}$ [2010] EWCA Civ 1335.

${ }^{21}$ See Argo Fund v Essar Steel [2006] EWCA Civ 241, where the relevant clause used the word "transfer" ([19]), a word which was construed to mean novation ([18], [60] and [63]).
} 
through the issue of a switch bill that does not reveal the identity of the person who originally shipped the goods. This practice becomes unobjectionable if the change in the shipper's name is viewed not as a misstatement of fact but as a contractual novation whereby the original shipper relinquishes its position in the contractual nexus and is replaced by its buyer, i.e. if the name of the shipper is viewed as an indication of the relevant person's contractual position $^{22}$ and not as a statement of who in fact shipped the goods.

One problem, however, with characterising as a novation the issue of a switch bill changing the name of the shipper to that of a buyer/ charterer in a trade chain is that it is usually requested by the buyer as holder of the bill of lading, meaning that the buyer in question will have already become the holder of the bill of lading through endorsement and/ or delivery of it to him by the shipper, making him in effect a party to the contract of carriage without the need for a novation. However, it may be argued that the issue of a switch bill changing the name of the shipper has additional effects to those of the transfer of a negotiable bill. ${ }^{23}$ In the former case the transferee acquires not only the rights but also the obligations ${ }^{24}$ of the shipper vis-à-vis the carrier, and the actual shipper's rights and obligations are extinguished. ${ }^{25}$ As a corollary, (if switching constitutes novation), the carrier will be able to exercise any rights granted to it by law against the shipper vis-à-vis the person newly designated as shipper only and not the actual shipper, and arguably any defences for breach of contract which it has against the "shipper" would only be exercisable if they apply to the person newly designated as shipper. ${ }^{26}$

The actual shipper should have no difficulty in agreeing to its ousting from the position of shipper (and could do so in advance by the inclusion of appropriate provisions included in or incorporated into the bill of lading contract), because important rights with respect to the cargo would arguably survive the novation regardless. For example, where English law is applicable to the sale contract in which the original (ousted) shipper is the seller, the unpaid seller's right to stop the goods in transit would be preserved, as this right is granted by law to

\footnotetext{
${ }^{22}$ See discussion of shipper's position in The Ardennes [1951] 1 KB 55, 59-60 and in Leduc v Ward (1888) 20 QBD 475.

${ }^{23}$ In Rasbora v JCL Marine [1977] 1 Lloyd's Rep. 645, although the novation of the contract took place at a time when the buyer to be substituted had already acquired property rights in the subject-matter of the sale, it was held to be relevant that contractual obligations remained to be performed: 'At the time when the substitution of Rasbora for Atkinson took place the following obligations remained to be discharged: J.C.L. had to hand over [the vessel]; the buyers had to take delivery of [the vessel]; subject to the part-exchange point, the buyers had to pay and the sellers had to accept tender of the price of [the vessel]. Therefore it is quite clear that the substitution of Rasbora for Atkinson was amply supported by consideration. The fact that under the terms of the original contract at the early stage of its construction [the vessel] became the buyers' property in my judgment does not affect the substitution I have mentioned. I regard this as the clearest possible case of a true novation.' (ibid, 650). Interestingly the fact that the substitute buyer was not a consumer was not held to have the effect of 'altering the rights and obligations of the parties as originally contracted for' (and therefore of altering the nature of the sale as a consumer sale. (ibid, 651).

${ }^{24}$ See e.g. the guarantee to be given by the shipper to the carrier in Hague-Visby Rules Article III (5); the liability with respect to dangerous goods in Article IV (6).

${ }^{25}$ Re rights, this also happens with transfer of a negotiable bill (see Carriage of Goods by Sea Act s 2(5)(a)). Re obligations see Aktion Maritime Corporation of Liberia v S. Kasmas Brothers Ltd and others (The Aktion) [1987] 1 Lloyd's Rep. 283, 301, which suggests that, if this is a novation, the actual shipper's obligations would be abrogated ab initio. Sections 2(5) and 3(3) of the Carriage of Goods by Sea Act 1992 would only serve to preserve the actual shipper's rights and liabilities insofar as such person can be considered on the facts as being 'the original party to the contract.' This would not necessarily be the case (e.g. in an FOB scenario where it is the buyer who enters into the contract of carriage).

${ }^{26}$ See e.g. the exclusion of the carrier's liability in Hague-Visby Rules Article IV (2)(i) for loss or damage arising or resulting from an Act or omission of the shipper or owner of the goods, his agent or representative.
} 
the seller regardless of whether or not such seller is the shipper of the goods. ${ }^{27}$ This would in effect mean that the price that the charterer pays for requesting the change of name is to take on the shipper's obligations and liabilities vis-à-vis the carrier. The shipowner/ carrier that agrees to a request for this type of switch from the charterer should also be aware that any recourse to the original shipper might be extinguished as a result.

\section{C.1.2 Change of Consignee}

The simple designation of a person as consignee in a bill of lading does not in and of itself make that person a party to the contract of carriage or give that person any right to enforce it. ${ }^{28}$ However, the Carriage of Goods by Sea Act 1992 (COGSA 1992) provides that such person can obtain rights of suit against the carrier, if it becomes the lawful holder of the bill, ${ }^{29}$ endorsement not being required for this purpose ${ }^{30}$ For this reason a change in the name of the consignee could be contractually significant in that it precludes the possibility of a certain person obtaining rights of suit against the carrier via a particular route (and conversely creates that possibility for a different person).

In terms of liabilities that might be acquired by being designated a consignee in a switch bill, the issue arose in The Sea Master, ${ }^{31}$ where a switch bill of lading was issued reflecting two changes: a change to the destination of the cargo and a change to the name of the consignee (with the new consignee being the bank financing the sale transaction). ${ }^{32}$ The switch occurred at the bank's counters. ${ }^{33}$ The substantive question that arose was whether 'the bank thereby [became] an original party to the bill of lading so as to come under liability to the shipowners on the terms of the contract of carriage contained in or evidenced by the bill of lading, including, for example, liability for shipment of dangerous cargo or demurrage...'. ${ }^{34}$ The cargo in this case was delivered to a sub-buyer, ${ }^{35}$ but because a number of sub-sales had fallen through before the sub-sale pursuant to which delivery was made, large amounts in demurrage had accrued, and the shipowner brought a counterclaim against the bank as consignee in respect of these amounts, when the bank claimed against it in respect of other cargo that had been on board the same vessel. ${ }^{36}$ The shipowner argued that the bank 'was the original party to the second switch bill under normal principles of contractual formation by reason of the circumstances in which it was issued and the Bank's involvement in its issue at the Bank's counters; and so owed the liabilities under the contract contained in it', which the bank denied, saying that it was not itself, but the charterer/seller, who had requested the switch, who was the original party to the switch bill contract (although the bank had

\footnotetext{
${ }^{27}$ See Sale of Goods Act 1979, s 39. See also facts of A.P. Moller-Maersk A/S (trading as Maersk Line) v Sonaec Villas Cen Sad Fadoul [2010] EWHC 355 (Comm) (hereinafter “Maersk v Sonaec Villas”), and discussion of the case infra.

${ }^{28}$ Under English law, contracts of carriage are excluded from the application of the Contracts (Rights of Third Parties) Act 1999. See s 6(5) and (6) of the Act.

${ }^{29}$ See Carriage of Goods by Sea Act 1992 (COGSA 1992), s 2(1)(a) and s 5(2).

${ }^{30}$ See interpretation of identical provisions in Singapore Bills of Lading Act 1994 by the Singapore Court of Appeal in UCO Bank v Golden Shore Transportation Pte Ltd [2005] SGCA 42 (hereinafter "UCO Bank"), [34] and [43].

31 Sea Master Shipping Inc v Arab Bank (Switzerland) Ltd (The Sea Master) [2018] EWHC 1902 (Comm); [2019] 1 Lloyd's Rep 101.

${ }^{32}$ The Sea Master (n 31), [1].

${ }^{33}$ The Sea Master (n 31), [18].

${ }^{34}$ The Sea Master (n 31), [1].

${ }^{35}$ The Sea Master (n 31), [19].

${ }^{36}$ The Sea Master (n 31), [20].
} 
consented to the switch and was the holder of the original bill at the time of the switch). ${ }^{37}$ Neither had the bank performed any of the actions listed in s 3 of COGSA 1992, whereby a lawful holder becomes 'subject to the same liabilities under the contract of carriage as if he had been a party to that contract.'

Unfortunately, this question was not decided by the court as it was deemed to be a matter to be decided by an arbitral tribunal, because the bank, when it had become a lawful holder of the bill of lading, had become bound by an arbitration clause incorporated in it. ${ }^{38}$ However one may express the view that, unless there is a novation replacing the contractual shipper (as discussed in section C.1.1 above), it is unlikely that the "original party" to the contract of carriage can be deemed to be changed by the issue of a switch bill.

Apart from these particular issues, a change in the designated consignee as between the carrier and any other person who is the lawful holder of the bill of lading would only constitute a variation rather than a novation of the contract of carriage, as it is simply an agreement by the carrier to deliver to a different person from the one originally agreed.

\section{C.1.3 Change of Carrier?}

An interesting question which may arise upon a switch bill being issued is whether it can be issued in such a way that there is in effect a change of contractual carrier (which could also be a contractual novation). This was alleged to have happened in a case brought before the Singapore courts. ${ }^{39}$ Here the holder of a bill of lading, M-Power, requested the issue of a switch bill to change the shipper's name so as to designate the holder as shipper and to add a detail to the description of the cargo. The switch bill was issued by Goodway who subsequently maintained that they had been acting as agents for VTC, the issuers of the substituted combined transport bill of lading, arguing that 'a switch bill of lading can only be issued by or for and on behalf of the carrier who issued the original bill of lading'. ${ }^{40} \mathrm{M}$ Power however asserted that 'there was nothing in Goodway's bill of lading that showed that they were acting as VTC's agents. ${ }^{41}$ The goods were delivered in the absence of the bill of lading and M-Power sued Goodway as carriers, obtaining judgment in default of appearance against them. The Assistant Registrar set aside the default judgment and M-Power appealed to the High Court which dismissed the appeal, holding that the matters raised by the dispute were to be considered at trial. Unfortunately, no decision on the merits appears to have been handed down, and it can only be conjectured that the dispute was eventually settled or resolved privately. If it had been established by M-Power that VTC was an undisclosed principal, Goodway, in spite of being agents, would have been liable as principals towards M-Power on the basis of the law relating to undisclosed principals. ${ }^{42}$ It is submitted that it is unlikely that M-Power would have been successful in alleging that it believed Goodway to be

\footnotetext{
37 The Sea Master (n 31), [22].

38 The Sea Master (n 31), [39]-[42]. According to the court's analysis, because COGSA 1992 s 2 treated a lawful holder "as if he had been a party to" the contract of carriage contained in or evidenced by the bill of lading, the section operated so as to make such holder a party to the arbitration clause and thus under the obligation to have any dispute falling within the scope of the arbitration agreement determined by arbitration, irrespective of whether the bank owed any substantive obligations under the contract of carriage.

${ }^{39}$ M-Power Development Pte Ltd v Goodway Agencies (Shipping) Pte Ltd [2003] SGHC 180, Singapore High

Court, (hereinafter "M-Power").

${ }^{40} M-P o w e r$ (n 39), [13].

${ }^{41}$ M-Power (n 39), [15].

${ }^{42}$ Siu Yin Kwan v Eastern Insurance Co [1994] 2 A.C. 199 (PC, Hong Kong).
} 
acting as principal, in view of the fact that M-Power was aware that the original bill of lading was issued by VTC as carrier. The same reasoning, however, would not apply to a transferee of the switch bill having no awareness of the switch or of the identity of the issuer of the original bill.

\section{C.1.4 Changes other than ones relating to the contractual parties}

Some of the reasons for requesting the issue of a switch bill of lading do not involve the substitution of a third party for one of the contractual parties and cannot therefore be characterised as novation of the contract. It is submitted that a request to change the port of discharge or to combine or split bills of lading should instead be viewed as a request to vary the contract of carriage. It is beyond the scope of this paper to examine the law governing contractual variation in detail..$^{43}$ Suffice to say that in the first case, consent to the variation would involve a change of voyage and discharge of the cargo at a different port. In the second case, consent to the variation would involve delivering different cargo amounts to a different number of consignees from what was originally agreed. In both cases, consideration for the change would consist of releasing the issuer from its obligations under the original bill.

\section{C.1.5 The effect of switching for the purposes of insurance}

It is worth bearing in mind that these changes would also have implications for insurance purposes. Cargo insurance certificates contain a description of the cargo and indicate the origin and destination of the goods. They may also indicate the name of the consignee and the bill of lading reference and its date. The issue of a switch bill changing any of these particulars may therefore make it harder to document an insurance claim convincingly should the cargo be lost or damaged, and a presentation of documents to a bank under a letter of credit may be rejected if there are discrepancies between the switch bill and the insurance certificate. ${ }^{44}$ If the switch bill is issued pursuant to a change of discharge port, a held-covered clause in the insurance contract may need to be brought into operation by notification and additional premium may need to be paid. ${ }^{45}$

\section{C.2 Who may request the switch?}

Where the issue of a switch bill of lading is requested, the receiver of the request must first determine whether the request derives from a person in a position to request a novation or variation of contract. This would depend on who the parties to the contract of carriage are at the time of the request, and, as illustrated by the case of Maersk $v$ Sonaec Villas, ${ }^{46}$ the answer to this question may not always be straightforward. This case did not involve a negotiable but a straight bill of lading that showed the buyer's name as consignee. Upon the buyer's failure to pay, the seller obtained a judgment from the Chinese court to the effect that it was entitled

\footnotetext{
${ }^{43}$ For a detailed discussion, see Chitty (n 19) Chapter 4, Section 9 and Chapter 22, Section 5.

${ }^{44}$ See International Chamber of Commerce (ICC), Uniform Customs and Practices for Documentary Credits 2007 (UCP 600), Article 14(d).

${ }^{45}$ See the Institute Cargo Clauses (A), (B) and (C) 2009, clauses 8.3, 9 and 10, esp. 10.1.

${ }^{46}$ Maersk $v$ Sonaec Villas (n 27).
} 
to possession of the bill 'as the owner and shipper of the cargo. ${ }^{47}$ Having obtained possession of the bill the seller requested a switch from the carriers (Maersk), who issued a bill of lading to the seller's order. The question arose whether the issue of the switch bill was in breach of the buyer's rights as consignee under the original straight bill of lading. More particularly, the question involved a determination of whether or not the buyer was an 'original party to the contract of carriage' or a party falling under s 2(1)(b) of the Carriage of Goods by Sea Act 1992 and who therefore had had 'transferred to and vested in him all rights of suit under the contract of carriage as if he had been a party to that contract.' Although the latter was the case, the buyer's rights as consignee were without prejudice to the 'shipper's right under the contract of carriage to redirect the goods, as he might wish to do if he was not paid for them.' 48

It is submitted that the analysis in the case raises some questions, as the wording of the original bill as reported in the case is ambiguous as to the identity of the shipper, ${ }^{49}$ and the contract of sale was on FOB Incoterms 2000 terms, which would normally entail arrangement of carriage by the buyer not the seller, ${ }^{50}$ so it is not entirely clear why the seller was deemed to be the 'original party to the contract' under s 2(5) of the Carriage of Goods by Sea Act 1992. It might have been more accurate on the facts to reason that the consignee's rights under the contract of carriage are without prejudice to the unpaid seller's right under sales law to stop the goods in transit and resume possession of them. ${ }^{51}$ However, the case does point to the need of caution when issuing a switch bill to ensure that the request derives from the person actually entitled to make it.

Further illustrations which bring home the extent to which this may be a complicated question to answer may be found in a Singaporean case and a Malaysian case. In Bandung 52 the original bills of lading were deposited with a bank (the claimant) by the holder with the intention of creating a pledge over the cargo, which operated to make the bank the lawful holder with rights of suit against the carrier. ${ }^{53}$ The bills were released back to the bank's customer for the purposes of facilitating the sale of the goods, but they were so released under a trust receipt which meant that the bank remained the pledgee of the cargo until the goods were sold and paid for. The customer used the bill to request and have issued to it

\footnotetext{
${ }^{47}$ Maersk $v$ Sonaec Villas (n 27), [10].

${ }^{48}$ Maersk $v$ Sonaec Villas (n 27) [35]-[39]. Note that it was the Chinese court that designated the seller as being the owner and shipper of the goods (ibid, [12]).

49 See Maersk v Sonaec Villas (n 27) [43]: 'Whether or not Yekalon [the seller] was, in truth, the shipper contracting with the carrier and thus (a) a party to clause 26 originally, and (b) able to direct that the cargo should not be delivered to Sonaec [the buyer] is less clear. Maersk asserts that that is so. The Chinese court has so ruled, but on evidence which is not before me. Moreover the First Bill was not directly in Yekalon's name. The named shipper was B \& D Co Ltd 'pour compte de' Vernal [a subsidiary of the buyer] and Yekalon. Vernal and Yekalon had potentially antithetical interests. It is not entirely clear what 'pour compte de' was supposed to signify and, in particular, whether B \& D was purporting to act as agent for both of them and, if so, in what respects.' See also ibid, [6] and [11].

${ }^{50}$ Maersk v Sonaec Villas (n 27), [5]. See Incoterms 2000, FOB, article B3(a): 'The buyer must contract at his own expense for the carriage of the goods from the named port of shipment.' It would appear however that the buyer can contract on both his own behalf and on that of the seller. See Maersk v Sonaec Villas (n 27), [45], where the court cited Pyrene $v$ Scindia [1954] 2 QB 402, 426 where Devlin J observed 'There is no difficulty in principle about the concept of an f.o.b. buyer making a contract of affreightment for the benefit of the seller as well as himself.'

${ }^{51}$ For English law on this point, see Sale of Goods Act 1979, ss 44 to 46, although note that this right would only apply in the case of the buyer's insolvency, and that no indication was given in this case that the buyer was insolvent.

52 Bandung (n 3).

${ }^{53}$ Bandung (n 3), [27].
} 
switch bills of lading. The reasons for switching were not clear. ${ }^{54}$ Eventually the switch bills were indorsed and delivered to the bank after the goods had been discharged, ${ }^{55}$ and the court held that the pledge survived the switch, and that while the customer was in possession of the switch bills, it was holding them in trust for the bank on the same terms as the original bills. ${ }^{56}$ Thus, although under clause 6 of the trust receipt, the customer undertook, prior to any sale, to return the cargo and documents on demand, the customer was still able to request and obtain a switch, presumably because it was in possession of the bills. So a pre-requisite for requesting a switch may be said to be possession of the original bill.

This was not the case in the dispute that came before the Malaysian courts. ${ }^{57}$ Here the sellers were in possession of the original bills of lading but the cargo was released against switch bills issued at the buyer's request, ${ }^{58}$ without surrender of the originals, ${ }^{59}$ by the delivery agent, ${ }^{60}$ without the contractual carrier's knowledge. ${ }^{61}$ The originals of course remained in effect giving the seller a remedy against the contractual carrier, who had authorised delivery against the switch bills. ${ }^{62}$ In taking its decision the court observed 'it is not in dispute that it is negligent if not wrongful, for a carrier to issue a second set of bills of lading in respect of the same cargo without the consent of the holder of the first set of bills of lading...'. This might be an indication that not only is it required that the person requesting the switch be in possession of the bill of lading, but that the consent of the person who is at law the holder (if this is a different person from the person in possession) to the switch also be obtained.

It is worth noting here that examples of charterparty clauses whereby carriers agree to issue switch bills of lading upon request (discussed further in section C. 3 below) normally confer upon the charterer the option to request the issue of the switch bill, specifying that this would be issued 'in exchange' for the existing bill. ${ }^{63}$ This implies that the charterer must be in possession of the original bill (or have obtained the consent of the person in possession) in order for the request to be made.

\section{C.3 The issuer's consent to the switch}

Whether the issue of the switch bill is characterised as a novation or variation of the contract of carriage, the consent of the issuer to the switch is key. Even though the switch has not been explicitly characterised as novation or variation in published cases, ${ }^{64}$ the need for the original issuer of the bill (or someone acting in the capacity of their agent) to authorise the switch has been emphasised. ${ }^{65}$ If the person requesting the switch is to be assured of obtaining it upon request, the consent of the issuer should be obtained in advance of the

\footnotetext{
${ }^{54}$ Bandung (n 3), [15].

${ }^{55}$ Bandung (n 3), [16].

${ }^{56}$ Bandung (n 3), [43].

${ }^{57}$ PT Karya Sumiden Indonesia v Oceanmasters Marine Services Sdn Bhd and Another [2016] 7 MLJ 589, High

Court of Kuala Lumpur (hereinafter "PT Karya").

${ }^{58}$ PT Karya (n 57), [30].

${ }^{59}$ PT Karya (n 57), [31].

${ }^{60}$ PT Karya (n 57), [30] and [26].

${ }^{61}$ PT Karya (n 57), [31].

${ }^{62}$ PT Karya (n 57), [109] and [111].

${ }^{63}$ See e.g. Bandung (n 3), [14]. The clause here also specified 'Strictly no double issuance of bs/l.'

${ }^{64}$ Although see reference to novation by counsel for the defendant shipowner in Daewoo Hong Kong $v$ Mana

Maritime Inc and others [1997] HKCFI 594 (Hong Kong) (hereinafter Daewoo v Mana), [18].

${ }^{65}$ See in particular Noble Resources v Cavalier Shipping Corporation (The Atlas) [1996] 1 Lloyd's Rep 642, esp. 649 .
} 
moment when the need arises, at the time of first entering into the contractual relationship. As a matter of practice, clauses may be included in charterparties whereby the owner or disponent owner agrees to issue switch bills in certain defined circumstances. ${ }^{66}$ Where these clauses are being relied on by the charterer in issuing the switch bills as agent for the shipowner, care must be taken to issue switch bills that actually comply with the terms of the clause. In the Hong Kong case of Islamic Republic of Iran Shipping Lines (IRISL) v Phiniqia International Shipping LLC and others ${ }^{67}$ both the fixture recap and the charterparty contained a similar term providing that a 'switch bill could be issued upon the pre-conditions of the surrender of the first set of the original bill and a letter of indemnity for the switch bill as per the owner's P\&I wordings. ${ }^{\prime 68}$ As the switch bill was issued in the absence of the surrender of the first set it was found to be in breach of contract and unauthorised, and therefore not binding on the shipowner. In another Hong Kong case, namely Daewoo Hong Kong $v$ Mana Maritime Inc and others,${ }^{69}$ the issue of a switch bill by the charterer changing the shipper's name was found not to have been authorised by the issuer of the original bill, there not being a clause expressing the necessary consent in the relevant charterparty. An interesting question that arises is whether a clause providing 'Bills of Lading shall be signed as Charterers direct, without prejudice to this Charter.... ${ }^{70}$ constitutes sufficient authority to permit the charterer to issue switch bills as and when it pleases. An observation in The Atlas suggests that a specific clause might be required for the necessary authorisation to be deemed given. $^{71}$

An ad hoc agreement to switch may also be made at the time that the switch is requested, however this agreement is likely to be made conditional upon the original bill of lading being surrendered, and the issuer would not be compelled to effect the switch unless this condition (and any other that may be imposed) is met. ${ }^{72}$

\section{C.4 Cancellation of the original bill}

A "switch bill" is only really a switch bill where the original bill of lading is surrendered in exchange for it and cancelled. If a new set of bills of lading is issued with respect to the cargo by the issuer or its authorised agent ${ }^{73}$ without cancellation of the old, the issuer is exposing itself to considerable liability. Precedent suggests that until surrendered and cancelled the first-issued bill of lading remains a document of title. ${ }^{74}$ In The Lycaon,${ }^{75}$ the court

\footnotetext{
${ }^{66}$ Examples of these clauses may be found in published cases. See e.g. Bandung (n 3), [14].

67 [2014] HKCFI 1280 (Hong Kong) (hereinafter IRISL v Phiniqia).

${ }^{68}$ IRISL v Phiniqia (n 67), [42].

${ }^{69}$ Daewoo v Mana (n 63).

70 See BP VOY 5 Clause 30.1.

${ }^{71}$ The Atlas (n 65), 649.

${ }^{72}$ See The Vasiliy Golovnin [2007] SGHC 116 (Singapore High Court, Admiralty). See also discussion in section C.4 infra.

73 Although it should be noted that in Hubbersty and Another $v$ Ward (1853) 8 Exchequer Reports (Welsby, Hurlstone and Gordon) 330; 155 E.R. 1374 it was held that 'when a captain has signed bills of lading for a cargo that is actually on board his vessel, his power is exhausted; he has no right or power, by signing other bills of lading for goods that are not on board, to charge his owner' (at 334). It is worth noting that this decision relied on the precedent in Grant v. Norway (10 C. B. 665) which has been widely regarded as problematic and was in effect "repealed" by the enactment of the Carriage of Goods by Sea Act 1992, s 4.

${ }^{74}$ Ishag $v$ Allied Bank, Fuhs and Kotalimbora [1981] 1 Lloyd's Rep. 92, 97. In the same case the second bill of lading which was put into circulation was described as being "false" and it was held that dealing with or disposition of it could not affect previously acquired rights (ibid, 98). See also UCO Bank (n 30), PT Karya (n 57) and Feoso (n 9).
} 
pronounced it 'irresponsible' on the part of carrier's agents to issue a second bill of lading to a firm of forwarding agents without the first bill having been surrendered and cancelled and without a very good explanation as to what had happened to the first bill. ${ }^{76}$ As a result of the issue of the second bill, and the consequent uncertainties as to who was entitled to delivery, the carrier decided not to deliver the goods upon arrival in Douala and the ship returned to Germany with the cargo still on board, giving rise to substantial costs which the cargo owners then sought to recover from the carriers as issuers of the second bill (a suit which was successful). Extended delays also occurred in The Vasiliy Golovnin, ${ }^{77}$ a Singaporean case, where the issue of a switch bill to change the port of discharge, which the carrier had agreed to, was never effected due to the failure on the part of the charterer to turn up with the original bill of lading (which at the time was held by a bank) at the appointed place. ${ }^{78}$ The court held that the carrier had acted reasonably in insisting that the cargo be discharged at the port of discharge indicated in the original bill, despite the sub-charterer's contrary instructions to discharge at a different port. ${ }^{79}$

Where a second bill of lading is issued without the first being surrendered and cancelled, this may constitute evidence of an intention to defraud. In Samsung v Devon Industries, ${ }^{80}$ a Singaporean case, the charterers who were FOB buyers of cargo colluded with the shipping agents in Singapore to issue freight pre-paid global bills of lading which they could pass on to their sub-buyers in exchange for payment prior to having themselves paid the seller (to whom were issued the original - which the court called the "authentic" 81 - bills of lading). The seller handed over the bills of lading to the buyer demanding payment, but no payment was forthcoming so the sellers sued for the retrieval of the authentic bills. The court found that, as the sale was on "cash against documents" terms, the buyers 'did not hold the documents beneficially but subject to the condition that they must make payment before they consider the documents their property' ${ }^{82}$ In the circumstances, the issue of the second set of bills of lading covering the same cargo without the surrender of the first, duly endorsed, constituted a fraudulent act on the part of the buyers/ charterers with the cooperation of the shipping agents. ${ }^{83}$ This meant that the sellers could demand the cargo from the shipowners. ${ }^{84}$ In view of the buyers/ charterers' insolvency, the shipowners would have to bear the loss.

The facts in Technical Waxes ${ }^{85}$ similarly strongly suggested fraud. The following extract, speaking of the evidence given by the fifth defendant, a shipping agent in Hong Kong, is worth reproducing in full:

'[The fifth defendant's] explanation of how he as a shipping man would issue [a switch bill of lading for a cargo of wax from Hong Kong to New Zealand and transhipment at Singapore, in place of a bill of lading showing shipment of that cargo

${ }^{75}$ Elder Dempster v Zaki Ishag (The Lycaon) [1983] 2 Lloyd's Rep. 548.

${ }^{76}$ The Lycaon (n 75), 552.

${ }^{77}$ The Vasiliy Golovnin (n 72).

${ }^{78}$ The Vasiliy Golovnin (n 72), [6].

${ }^{79}$ The Vasiliy Golovnin (n 72), [67].

${ }^{80}$ Samsung Corp v Devon Industries Sdn Bhd [1996] 1 SLR 469 (Singapore) (hereinafter "Samsung v Devon Industries").

${ }^{81}$ Samsung v Devon Industries, (n 80) [2], [11], [12].

${ }^{82}$ Samsung v Devon Industries, (n 80) [22].

${ }^{83}$ Samsung v Devon Industries, (n 80) [10].

${ }^{84}$ Samsung v Devon Industries, (n 80) [27].

${ }^{85}$ Technical Waxes (NZ) Ltd. v Ho Hoa Meng and others [1980] HKCFI 161; HCCL 33/1980 (Hong Kong High Court Commercial List), [6]. 
of wax from Singapore to Hong Kong for transhipment to New Zealand] knowing that the ship was never in Hong Kong is beyond belief. I can appreciate a shipping man issuing a switch bill of lading in a case where he knows that the ship is really in port and that the cargo is on board. But the original bill of lading which he said he got from the $2^{\text {nd }}$ Defendant [(]and the $2^{\text {nd }}$ Defendant denied that he ever gave it to him[)] showed clearly that it was issued by the $3^{\text {rd }}$ Defendant. It certainly does not make sense to any reasonable man that somebody would ship a cargo of wax from Singapore to Hong Kong so that the same goods would be shipped back on the same ship to Singapore for discharge and then trans-shipment to New Zealand.... The issue of the bill of lading to the $2^{\text {nd }}$ Defendant under his own signature was issued fraudulently knowing full well that the goods had not been loaded on board the vessel.'

This demonstrates that while largely a legitimate practice, the issue of switch bills of lading can also be abusive and used as an instrument for fraud, and indicates that carriers should be vigilant of the actions of agents authorised to issue bills on their behalf. ${ }^{86}$

\section{C.5 Mandatory rules of public international law}

Where the issue of a switch bill of lading constitutes a novation or variation of the contract, it is important to examine what effect, if any, its issue has on the application of mandatory rules of public international law. Issues may arise in two scenarios: (i) if the switch bill is issued in a jurisdiction that applies a different international transport convention from that applicable to the contract contained in the original bill; and (ii) if the switch bill shows a different port of loading or a different port of discharge from the original. In either of these scenarios, two questions may arise: (a) does a different regime apply to the contract contained in the switch bill from the regime that applied to the original? And (b) if yes, will the application of the substitute regime (which would result in a different package limitation and perhaps also different exclusions of liability for the carrier) be upheld?

In relation to question (a) it is to be noted that the determinants under the different conventions of when the convention applies vary. The only determinant found in Article 10 of the Hague Rules is the place of issue of the bill of lading. ${ }^{87}$ Under Article X of the HagueVisby Rules among the alternative determinants of whether the Rules apply to a particular carriage contract are listed both the issue of the relevant bill of lading in a Contracting State and carriage from a port in a Contracting State. In the Hamburg Rules the list of determinants is much longer and they are worded slightly differently. The Rules are held to apply if, among other things,

(a) the port of loading as provided for in the contract of carriage by sea is located in a Contracting State, or

\footnotetext{
${ }^{86}$ On the perils of permitting agents to issue switch bills, see also PT Karya (n 57).

${ }^{87}$ Note that Vita Food Products v Unus Shipping Company [1939] AC 277 (PC, Nova Scotia, Canada) brought to light a gap which 'enabled the Rules, at any rate in theory, to be evaded by a choice of law clause for a jurisdiction which either had not adopted the Rules at all or did not apply them to that voyage.' (F Reynolds, 'The Hague Rules, The Hague-Visby Rules and the Hamburg Rules' (1990) 7 MLAANZ Journal 16, 20). In this case English law had been chosen to govern a contract of carriage of goods between Newfoundland and New York, and although the Rules had been enacted as the English Carriage of Goods by Sea Act 1924, Article 10 of the Hague Rules was not enacted into English law (Reynolds, ibid, 22) and the Act applied the Rules only to outward shipments from the United Kingdom.
} 
(b) the port of discharge as provided for in the contract of carriage by sea is located in a Contracting State, or

(c) one of the optional ports of discharge provided for in the contract of carriage by sea is the actual port of discharge and such port is located in a Contracting State, or

(d) the bill of lading or other document evidencing the contract of carriage by sea is issued in a Contracting State, $\ldots .{ }^{88}$

If different regimes apply respectively in the place where the original bill is issued and the place where the switch bill is issued, or if the switch is effected to change the name of the port of loading or the port of discharge, conflicts may well arise, and the issuer should be aware that, if this is considered a novation or a variation of contract, it may constitute a change in its liability (subject to the answer to question (b)). Toh observes that

'if an analogy is drawn with cases where goods originating from a [Hague-Visby]

Contracting State are transhipped at a non-Contracting State, [the Hague-Visby

Rules] should continue to apply thereafter. But there is no exact parallel with transhipment, at least one in which through bills are used, since the original bill which embodies the contract of carriage to which the Rules apply becomes spent upon being surrendered.... [But] if the actual place of shipment is a Contracting State, the insertion of a different place of shipment in the switch bill should not displace the Rules. ${ }^{\prime 89}$

With respect, it would appear that, at least if the place of shipment inserted applies the Hamburg Rules, this would not be the case. One should note here that where the switch bill indicates a different port of loading from that indicated in the original bill, this may be problematic in and of itself, as a declaration that goods were loaded at port A when in fact they were loaded at port B would surely constitute a misrepresentation, ${ }^{90}$ although if the goods are transhipped at an intermediate port and a new bill of lading is issued to show the port of transhipment as the port of loading, this issue may not arise. ${ }^{91}$ It should also be noted that, in situations where the switch bill indicates a different port of loading from the original because the actual port of loading was in a state subject to a sanctions regime, it is not unlikely that, in case of a dispute, the switch bill contract would be declared void and unenforceable because of illegality or because upholding it would be contrary to public policy. Both these risks are discussed further in sections D.2 and D.4. The present discussion will be concerned with the question of which International Transport Convention would be applicable to the holder of the switch bill.

If switching constitutes a contract variation, and as the holder of the switch bill would never have been a party to the original bill of lading contract, one may hazard a guess that applicable regime would be that which applies at the port of loading indicated in the switch bill. A problem would of course arise if (some of) the goods were lost or damaged or if their condition changes for any reason between departing from the actual port of loading and

\footnotetext{
${ }^{88}$ Emphasis added.

${ }^{89}$ Toh (n 12), 421.

${ }^{90}$ In The Saudi Crown [1986] 1 Lloyd's Rep. 261 backdating of the bill of lading by the issuer's agent to show a loading date of $15^{\text {th }}$ July 1982 rather than $26^{\text {th }}$ July 1982 when the loading was in fact completed, was held to be a fraudulent misrepresentation for which the issuer was liable.

${ }^{91}$ It is to be noted, however, that in the case of a cost insurance freight (c.i.f.) transaction the issue of a switch bill at the port of transhipment may be problematic as the buyer is entitled to full documentary coverage. See discussion of Hansson v Hamel \& Horley Ltd (1922) 10 Ll.L.Rep. 507; [1922] 2 AC 36 (hereinafter "Hansson") in section D.2. All references below are to the case report published in [1922] 2 AC 36.
} 
reaching the port indicated in the switch bill. In this case, as between buyer and seller, the risk of the damage or deterioration would surely need to be borne by the seller, especially since the switch bill would usually be issued at the seller's request. Risk could only be deemed to have passed to the buyer upon (notional) shipment at the port of loading indicated in the switch bill. Cases of gradual and incremental deterioration would of course be the hardest to resolve, especially if the cargo is not surveyed and tested at the port of loading designated in the switch bill. If the loss, damage or deterioration was caused by an act or omission of the carrier for which the carrier is liable under the regime applicable at the actual port of loading, it may be doubtful whether the seller/ shipper would have recourse against the carrier with respect to the loss, if the variation of contract analysis is correct, i.e. if the consideration given to the carrier by the seller/ shipper for entering into the varied (switch bill) contract is to release the carrier from its obligations under the original contract.

More generally, difficulties will arise where the place of issue of the switch bill imposes a regime which grants wider rights to the holder and imposes more onerous obligations on the carrier than the regime applicable in the place of shipment, a scenario which would call into play question (b). The Atlas ${ }^{92}$ suggests that in this situation the regime applicable by the law of the place of issuance of the switch bills will apply to the switch bills. Even if the place of shipment of the goods is still stated as being the actual place of shipment, a different liability regime from that of the port of loading could apply to the contract. While, as observed by Toh, ${ }^{93}$ this would retrospectively alter rights and liabilities that accrued under the original bill, for instance, damage to cargo sustained during loading, it is submitted that it is open to the carrier through a contract variation, to agree to assume more onerous obligations than those imposed by the regime mandatorily applicable under the original bill of lading contract. ${ }^{94}$ Problematically, the substitute regime may impose less onerous liabilities on the carrier, in which case, whether this contract variation would be upheld would depend on whether it were considered an attempt to circumvent mandatory rules of law. ${ }^{95}$ Thus, a replacement of the Hamburg Rules by the Hague or Hague-Visby Rules, or a replacement of the Hague-Visby Rules by the Hague Rules may well be struck down. ${ }^{96}$

\section{The risks of consenting to the issue of switch bills}

As shall be seen below, the issue of switch bills of lading is fraught with risks for the carrier, who might nevertheless agree to it for commercial reasons. ${ }^{97}$ Understanding these risks is crucial to taking preventive and mitigating action.

\section{D.1 The risk of fraud against buyer and seller.}

As illustrated by cases such as Samsung $v$ Devon, ${ }^{98}$ IRISL $v$ Phiniqia, ${ }^{99}$ and PT Karya ${ }^{100}$ discussed above, the issue of a switch bill of lading may be illegitimately requested by a

\footnotetext{
92 The Atlas (n 65), 646.

93 Toh (n 12), 421.

${ }^{94}$ In this regard, see discussion in R Williams, 'Letters of Indemnity' (2009) 15 (5) Journal of International Maritime Law, 394-410.

95 See The Morviken [1983] 1 Lloyd's Rep. 1, 5-7; The Hollandia [1983] 1 AC 565, 572-578.

96 See The Hamburg Rules, Article 23(1) and Hague-Visby Rules, Article III(8).

${ }^{97}$ In Bandung (n 3), [15], the court noted that '[t]he provision for a new set of bills of lading is often agreed by shipowners for commercial motives, but it is undoubtedly an accommodation that is not without risks.'

98 Samsung v Devon, (n 80).
} 
buyer to enable it to obtain payment from a sub-buyer for goods for which it has not yet paid its seller. In these cases, the switch bill was issued while the original bill was still in circulation. However, for the issuer of the original bill, the respective outcomes were rather different. In IRISL, the issuers of the original bill did not authorise the issue of the switch bill. By contrast, in Samsung, the issue of the second set of bills was done in collusion with the shipping agents, and in PT Karya, the agents were found to have been authorised to issue the switch bills, so that in both these cases the issuers of the original bills were found to be liable. The cases demonstrate that it is incumbent upon the issuer to ensure that authorisation to issue switch bills is given on restrictive terms and that those authorised to waive those restrictive terms by reason of their position as agents with apparent or ostensible authority ${ }^{101}$ are properly monitored.

\section{D.2 The risk of liability for misrepresentation/mis-description}

As already mentioned above, a bill of lading switch that does not also entail a contractual novation or variation can be tantamount to knowingly including a misrepresentation or misdescription in the bill of lading. The holder of such a bill will be entitled to a remedy if it suffers a loss as a result of becoming a party to the contract of carriage by accepting the bill. ${ }^{102}$

The question arises, would dating the switch bill with the same date as that of the original bill of lading constitute a misrepresentation? It is worth noting here that in the case of a cost insurance freight (c.i.f.) transaction the buyer may be entitled to reject the tender of a switch bill showing a date later than the actual shipment of the goods. In Hansson, ${ }^{103}$ it was held that in a sale on c.i.f. terms the contract of affreightment must be procured on shipment, and that a bill of lading issued thirteen days after the original shipment at another port in another country was not procured on shipment. The switch bills were 'to be signed in Hamburg upon presentation of the local bills of lading', ${ }^{104}$ the latter being the bills of lading issued in Norway, the place of origin. They contained the same details as did the local bills, except for the date of issue, but the c.i.f. buyer was still entitled to reject. ${ }^{105}$ A perusal of the reasoning in the case suggests that the contractual effects of certain notations on the switch bill (specifically, whether they constituted undertakings by the issuer or a mere recital of facts) were unclear, meaning that the holder's rights against the issuer with respect to the journey between Braatvag in Norway and Hamburg were uncertain, ${ }^{106}$ so that the bill of lading

\footnotetext{
${ }^{99}$ IRISL v Phiniqia (n 67).

${ }^{100}$ PT Karya (n 57).

${ }^{101}$ Re apparent or ostensible authority see Freeman \& Lockyer v Buckhurst Park Properties (Mangal) Ltd [1964] 1 All ER 630.

${ }^{102}$ In this regard see Misrepresentation Act 1967, s 2(1). See also Brown Jenkinson \& Co Ltd v Percy Dalton (London) Ltd [1957] 2 QB 621 (hereinafter Brown Jenkinson v Percy Dalton) (discussed further below); James Finlay and Co v NV Kwik Hoo Tong Handel Maatschappij [1929] 1 KB 400; Kwei Tek Chao v British Traders \& Shippers Ltd [1954] 2 QB 459; Proctor \& Gamble Philippine Manufacturing Corpn v Kurt A. Becher [1988] 2 Lloyd's Rep 21, 29-30.

${ }^{103}$ Hansson (n 91).

${ }^{104}$ Hansson (n 91), 38.

${ }^{105}$ See also NV Arnold Otto Meyer v Aune [1939] 3 All ER 168. Note that there is no reference to any obligation to provide continuous documentary cover in CIF Incoterms 2010, Article A8. Article A3(a) provides: 'The seller must contract or procure a contract for the carriage of the goods from the agreed point of delivery, if any, at the place of delivery to the named port of destination or, if agreed, any point at that port.'

106 Hansson (n 91), 45.
} 
tendered was not really a through bill of lading. ${ }^{107}$ But the case does raise a potential problem where a switch bill that needs to be tendered in fulfilment of a c.i.f. contract obligation is issued many days later than and at a different place from the original bill.

Therefore, there may be good reasons for dating the switch bill with the same issue date as the original bill, in spite of the fact that it was issued subsequently, but the question arises whether this would constitute a misrepresentation. Under the UCP 600, Article 20(a)(ii),

'The date of issuance of the bill of lading will be deemed to be the date of shipment unless the bill of lading contains an on board notation indicating the date of shipment, in which case the date stated in the on board notation will be deemed to be the date of shipment.'

This may indicate a practice whereby the date of issue on the bill can signify the date of shipment of the goods. If this is indeed the case, back-dating the issue date of a switch bill to show the date of shipment might not constitute a misrepresentation, as the goods would in fact have been shipped on the relevant date. There are also indications that, when issuing switch bills of lading for the purpose of splitting bulk cargo, the practice is to date them with the date of the original bill. ${ }^{108}$ However, as the IRISL case demonstrates, ${ }^{109}$ in a subsequent dispute, particularly where fraud is alleged, the holder would not be prevented from disputing the date of issue indicated. A less risky approach would probably be to indicate the actual issue date together with a notation that the switch bill is issued to substitute a bill issued earlier and to indicate the date of issue of the substituted bill.

\section{D.3 The risk of loss of P\&I cover and unenforceability of indemnity given}

P\&I Clubs publish advice to their members regarding the appropriate process to follow when issuing switch bills. ${ }^{110}$ They emphasise the need to ascertain that the person making the request is entitled to do so, that consent of all relevant parties is obtained, that the wording to appear in the substitute bill is not such as to mislead, that there is a clear and legitimate reason for the switch, that all original bills are held by the requestor and that they are ready for surrender and cancellation and that any indemnity given in exchange for the switch is enforceable. To what extent failure to do any of these things will lead to a loss of P\&I cover will depend on the applicable terms of cover in each case.

\footnotetext{
${ }^{107}$ Hansson (n 91), 48.

${ }^{108}$ See Gard, Gard Guidance on Bills of Lading, undated, available electronically at http://www.gard.no/Content/20651968/Gard+Guidance+bills+of+lading+March+2011.pdf [accessed

26.04.2019], section 4.5: 'If ... a request [to issue split bills of lading] is made all the original bills of lading of the set first issued for the consignment to be split should be surrendered and replacement bills of lading issued. Care must be taken to ensure that the total amounts of cargo stated in the split bills of lading equals the amount in the original bill of lading, and the information, e.g. the description of the cargo and date, is the same.

(Emphasis added).

${ }^{109}$ IRISL v Phiniqia (n 67), [45]-[47].

${ }^{110}$ See for example advice published by the Standard Club dated $16^{\text {th }}$ October 2014 , available electronically at http://www.standard-club.com/news-and-knowledge/news/2014/10/web-alert-switch-bills-of-lading.aspx

(accessed 30-06-2017) and by Gard, 'English Law - Switching Bills of Lading', Gard News 201, February/April 2011, available electronically at http://www.gard.no/web/updates/content/12026470/englishlaw-switching-bills-of-lading (accessed 30-06-2017).
} 
It is because of the risk of loss of cover that the issuer will normally require an indemnity from the person requesting the issue as a condition to acceding to the request. ${ }^{111}$ In these cases, the issuer or its agent must ensure that its acts in issuing the switch bill are within the scope of what is requested in the indemnity, i.e. that the instructions in the indemnity are followed to the letter. ${ }^{12}$ As put by Manaadier:

'If the agent has been asked by the principal to issue the switch bill of lading based on an indemnity from the customer, the agent should ensure to get the wording format from the principal and get the completed indemnity approved by the principal before issuing the switch bill of lading.' ${ }^{\prime 13}$

Even when this is done, caution must be exercised in placing too much reliance on the indemnity. In particular, if the switch is requested for an unlawful purpose, the indemnity would most likely be unenforceable, depending on the knowledge of the issuer. In Brown Jenkinson $v$ Percy Dalton ${ }^{114}$ it was held that an indemnity given in exchange for an agreement by shipowners' agents to issue a clean bill of lading in respect of cargo known to be defective and knowing that the description in the bill would be relied on, was unenforceable as it was an agreement to make a fraudulent misrepresentation. ${ }^{115}$ From a reading of The Jag Ravi ${ }^{116}$ one may conclude that an indemnity given to a person in exchange for agreeing to act for the achievement of what is known to that person to be an unlawful purpose is unenforceable. ${ }^{17}$ It is submitted that such a purpose would include not just fraud but also circumvention of applicable administrative laws (such as laws relating to imports, tax or sanctions).

\section{D.4 The risk of lack of enforceability for illegality}

Cargo owners have been known to request the issue of switch bills to circumvent import and export prohibitions or sanctions prohibiting dealings with oil-rich states. An illustration of the former may be found in the case of Feoso. ${ }^{118}$ Here the switch bills were issued by an agent without actual authority against an LOI addressed to the actual carrier (the shipowner) but not received by it. The shipowner refused to deliver against the switch bills and insisted on the original bill which was still in circulation. However, the description of the cargo in the original bill made it an illegal import in China (the agreed destination) and the switch bill was issued to change the description. The court held that the shipowner's decision to leave Huangpu without discharging the cargo was reasonable in the circumstances. ${ }^{119}$

As for the attempt to circumvent sanctions, a couple of published cases hint at the attempt to use switch bills to this end. For example in the IRISL case it was noted that 'GEG is an Iranian company subject to sanctions imposed by the United Nations Security Council; and therefore Tradeline would have difficulty negotiating the shipping documents through banks

\footnotetext{
${ }^{111}$ See e.g. clauses referred to in The Atlas (n 65), 644, IRISL v Phiniqia (n 67), [42].

${ }^{112}$ See The Bremen Max [2008] EWHC 2755 (Comm).

${ }_{113}$ Manaadiar (n 4).

${ }^{114}$ Brown Jenkinson v Percy Dalton (n 102).

115 Brown Jenkinson v Percy Dalton (n 102), 638-9.

${ }^{116}$ Great Eastern Shipping Co Ltd v Far East Chartering Ltd (The Jag Ravi) [2012] EWCA Civ 180.

117 The Jag Ravi (n 116), [50]-[52].

${ }^{118}$ Feoso (n 9).

${ }^{119}$ Feoso (n 9), [73].
} 
if the Original B/L were not switched. ${ }^{\prime 20}$ In Sea Glory Maritime v Al Sagr ${ }^{121}$ defendant insurers made a late application to amend their points of defence as evidence had come to light that the claimants, assureds under a marine policy, had agreed to issue false switch bills of lading in order to circumvent regulations governing trade with Iran. ${ }^{122}$

In these situations, the switch bills would likely be issued in order to change the name of an Iranian shipper or the name of an Iranian port of loading. Even if the change did not constitute a misrepresentation (e.g. because the change of shipper occurred as a result of a contract novation, or because a broad description of the port of loading were used e.g. "one middle eastern port"), it is submitted that the switch would have occurred for an unlawful purpose, and the courts would be unlikely to enforce a claim, whether by carrier (e.g. for freight or demurrage) or by shipper (e.g. for loss of or damage to the goods), that were reliant upon the illegal novated or varied contract. ${ }^{123}$ As the transportation of, for example, a transhipped oil cargo originating from Iran, which is currently subject to US sanctions, could put the carrier in violation of sanctions, ${ }^{124}$ shipowners would be well-advised to include in their charterparty contracts a sanctions clause such as those proposed by INTERTANKO and BIMCO. ${ }^{125}$ Such clauses would entitle them to refuse to issue switch bills for these purposes no matter how broad are the terms of their agreement to issue bills of lading as charterers direct.

\section{E Mitigating these risks: can digitalisation help?}

Many of the risks discussed in section D stem from the fact that where information is recorded on paper the multiple parties and service providers typically involved in international trade transactions do not all have adequate access to reliable and consistent information about the goods themselves or a way of confirming who has rights over the goods. Thus, persons other than the lawful holders of the original bills of lading may request the issue of switch bills, agents acting or purporting to act on behalf of carriers may be prevailed upon to issue (or collude with a fraudster in issuing) switch bills without the

\footnotetext{
${ }^{120}$ IRISL v Phiniqia (n 67), [41].

${ }^{121}$ Sea Glory Maritime Co. and Swedish Management Co SA v Al Sagr National Insurance Co [2012] EWHC

874 (Comm) (hereinafter Sea Glory Maritime v Al Sagr).

122 Sea Glory Maritime v Al Sagr (n 121), [2], [3] and [5].

${ }^{123}$ Patel v Mirza [2016] UKSC 42.

${ }^{124}$ See ITSR (n 8), 31 CFR $§ 560.211(\mathrm{c})(1)(\mathrm{ii})(\mathrm{B})$

${ }^{125}$ Intertanko sanctions clause available at INTERTANKO, INTERTANKO Commentary on BP VOY 5 ,
} (INTERTANKO, 2016), Appendix 3: INTERTANKO Suggested Additional Clauses for BP VOY 5, 114. See also Mandatory Additional Clause 4 available ibid, Appendix 6: Extracts BP VOY 4 Standard Amendments and Additional Clauses, 195. See also BIMCO Sanctions clause for time charterparties (available at www.bimco.org, accessed 30.06.2017). In the explanation of the same, it is noted:

'Of particular concern is that involvement by foreign entities in the importation of refined petroleum products (diesel, gasoline, jet fuel (including naptha-type and kerosene-type jet fuel), and aviation gasoline) into Iran, or any assistance in the development of Iran's domestic refining capability, may result in sanctions imposed not only on foreign shipowners (including parent companies), but also on the crew and those who provide services, information and insurance to the vessel such as managers, the ship's insurers and their re-insurers.

'The penalties for breaking the US sanctions are severe and may result in foreign businesses that break the sanctions finding their dollar transactions blocked by the US banking system. Many P\&I Clubs have already implemented Rule changes whereby cover will be terminated if a member engages in trades likely to expose the Club to sanctions.

'The objective of the new Clause is to provide owners with a means to assess and act on any voyage order issued by a time charterer which might expose the vessel to the risk of sanctions. The test is one of "reasonable judgement" by the owners in determining whether the risk of the imposition of sanctions is tangible.' 
original bills being surrendered, and subsequent holders of the switch bills may be completely unaware that what they are holding gives them no rights against the carrier (in that it was issued without authority), or is tainted by illegality (making those rights unenforceable). The recording of information normally communicated by the contents of a paper bill of lading, or by the fact of its holdership, in a centralized or distributed ledger, either of which will provide a "single source of truth" could do much to address these areas of opacity and ensure that risks associated with switching bills of lading are mitigated.

The use of electronic alternatives to paper transport documents has been gaining ground in recent years. In 2013, the International Group of P\&I Clubs agreed to cover the liability risks arising from the use of certain systems. ${ }^{126}$ In 2014, BIMCO drafted and adopted a model clause on Electronic Bills of Lading (EBL clause) for use in its charterparties. ${ }^{127}$ Subsequently, in 2016 upon the update of the BP VOY form of charterparty, provisions contemplating the use of electronic bills of lading were introduced in BP VOY $5 .{ }^{128}$ These standard provisions have been introduced in response to rising use of these systems which is increasingly promoted by chartering multinationals, among them the oil majors. ${ }^{129}$ More recently, there has been much interest in the possibility of building systems to take over the functions of paper bills of lading which are underpinned by distributed ledger technology, and in particular, blockchain. ${ }^{130}$

How could such systems assist in mitigating the risks arising from the issue of switch bills? First, the system can be designed so as to make it impossible to issue a substitute for a bill issued over the system without the express agreement of the original issuer (or someone designated over the system as authorized to act on its behalf) and without the cancellation of the original bill, which only the current holder would be able to request. If carriers required

\footnotetext{
${ }^{126}$ See UK P\&I Club Circular Ref. 6/13, Electronic (Paperless) trading systems - Electronic Shipping Solutions \& Bolero International Ltd. - Updated ESS DSUA Version 2013.1, March 2013, available electronically from http://www.ukpandi.com/ (accessed 01.07.2017). P\&I Clubs now provide cover for typical P\&I Club liabilities arising under any electronic bill of lading to the extent that these liabilities would also have arisen had a paper bill of lading been used. Had the particular liability not have arisen had a paper bill been used, the liability will still be covered by the Club, however cover is discretionary unless the electronic system used were one approved by the International Group of P\&I Clubs. See UK P\&I Club, Paperless Trading (Electronic Bills of Lading) - Frequently Asked Questions, available electronically from http://www.ukpandi.com/ (accessed 27.08.2015), Question 2. The two systems initially approved were Bill of Lading Electronic Registry Organisation (Bolero) http://www.bolero.net (accessed 01.07.2017) and essDOCS (formerly known as Electronic Shipping Solutions or ESS) http://www.essdocs.com/ (accessed 01.07.2017). A third system has since been approved. This is e-title, provided E-Title Authority Pte Ltd, approved by the International Group of P\&I Clubs in October 2015. See UK P\&I Club Circular 12/15 dated $22^{\text {nd }}$ October 2015 available electronically at http://www.ukpandi.com/fileadmin/uploads/uk-pi/Latest_Publications/Circulars/2015/UK_Circular_1215.pdf (accessed 01.07.2017). The liabilities which might remain uncovered if an unapproved system is used include those arising from a successful legal challenge to the system's ability to transfer rights over the goods as intended, or from the ineffective incorporation of the Hague or Hague-Visby Rules (which may not apply automatically where a paper bill of lading is not used). Ibid, Question 5. See also discussion in M Goldby, Electronic Documents in Maritime Trade: Law and Practice (OUP, 2013), [6.14] - [6.18].

${ }^{127}$ Baltic and International Maritime Council (BIMCO), Electronic Bills of Lading Clause for Charterparties, BIMCO Special Circular No. 3, $20^{\text {th }}$ May 2014 (hereinafter "BIMCO Special Circular").

${ }^{128}$ See BP VOY 5 clauses $30.3-30.6$.

${ }^{129} \mathrm{BP}$ VOY is a proprietary form drafted by one of the oil majors who frequently charter oil tankers. Electronic bills have been widely championed by the oil majors most of which, including Shell, BP, ExxonMobil, Chevron and Total subscribe to the essDOCS system, however this is also true of the dry bulk sector: see BIMCO Special Circular (n 127), 1.

${ }^{130}$ For an overview of the different pilot projects based on blockchain technology see E Ganne, Can Blockchain Revolutionize International Trade? (World Trade Organisation (WTO), 2018) available online at https://www.wto.org/english/res e/publications e/blockchainrev18 e.htm [accessed 8 February 2019], 41-45.
} 
switch requests to be made over the system, authorized persons on the issuer end would be alerted to the reasons for requesting the switch and would be in a position to make quick decisions on whether to assent to it, without the need to delegate these important decisions to agents whose trustworthiness (or competence) may be doubtful. The surrender of the original bill and the issue of the switch bill to the same person would also be instantaneous and, the carrier would have real time information about contractual terms and entitlements so that there would be no doubt at destination who may be entitled to delivery of the cargo. Indeed, the system would create an audit trail giving the issuer clarity on its obligations with respect to the particular goods. The danger of switch requests being agreed to by unauthorised persons would be obviated as only authorised persons would have the security credentials required to transact over the system. The system could also be designed to indicate the fact of substitution on the switch bill itself, which would provide subsequent holders with more clarity on their position.

In view of the protection they are able to afford issuers, it is surprising that INTERTANKO recommends the deletion of provisions in Clause 30 of BP VOY 5 permitting the charterer to require use of the essDOCS system for the issue, signing and transmission of bills of lading. ${ }^{131}$ The reason may be that the use of the system requires a shipowner to subscribe to the system and employees in charge of issuing bills of lading on its behalf to know how to use the system. In other words, it would not be advisable for shipowners to accept the insertion of the clause unless they have already made (or are prepared to make) arrangements for using the system to which it refers. Where adopted, however, systems which provide visibility into contractual terms and entitlements could do much to mitigate the risks involved in switching bills of lading.

\section{F. Conclusion}

The aim of this paper was to provide a legal analysis of the practice of issuing switch bills of lading and to highlight the attendant risks, as well as to provide some insight into how these risks may be mitigated. Provided it is done with the authority of the issuer of the original bill, the issue of a switch bill of lading may constitute a novation or variation of the contract of carriage. It may thus change the legal position of the issuer, whether because a new person has been placed in the position of shipper, because its performance obligations have changed in some significant way, or because a different international convention applies to the contract of carriage. Depending on the nature of the request, the issue of a switch bill of lading may leave the issuer open to liability for fraud or misrepresentation, or for colluding to circumvent sanctions, and may lead to the loss of P\&I cover. If any LOI given to the carrier in exchange for issuing the bill were deemed unenforceable, the issuer could be exposed to very serious losses.

These risks may be mitigated by giving careful attention to the preconditions for requesting a switch. Clauses could be included in charterparties indicating that a switch bill will only be issued in exchange for the original bill (or if it can be shown that the original bill has been irretrievably lost or destroyed), that requests to switch must come from the holder of the bill of lading, and that they must be acceded to by certain designated persons on behalf of the issuer of the original bill. These clauses could also specify in advance the particular circumstances where a switch will not be acceded to (including where the issue would

${ }^{131}$ See INTERTANKO (n 125), Appendix 1: INTERTANKO Suggested Amendments to BP VOY 5, 99. 
constitute a misrepresentation or a circumvention of applicable laws). They could also require that an LOI be provided by the person requesting the switch, with countersignature by a financial institution where that person's credit standing is in any doubt. As seen in section C.3, these clauses can prevent the carrier from becoming liable for the actions of purported agents who issue the switch bill without the preconditions being met.

Consideration could also be given to adopting electronic alternatives to bills of lading, which would give issuers and holders alike visibility into contractual terms and entitlements. This visibility could do much to mitigate many of the risks discussed above. 